\title{
A Case-Control Study of Skin Microbiome in Patients with Lamellar Ichthyosis
}

\author{
Mehak SINGH${ }^{1}$, Manoj PAWAR ${ }^{2}$ \\ ${ }^{1}$ Department of Dermatology, RKDF Medical College and Hospital,Bhopal, India. \\ 2MVP's Dr.V.P Medical College\& Hospital \& Research Center, Nashik, India \\ Correspondence: Mehak Singh, Email: med.mehak@gmail.com \\ UDC 616.5-056.7:579.61
}

\begin{abstract}
Introduction: Lamellar ichthyosis is a genetic disorder of keratinization and the frequent skin infections in these patients may be a result of change in normal skin flora acting in addendum to breach in the physical barrier. Material and Methods: A comparative retrospective study was performed in patients with lamellar ichthyosis and age/ sex controlled matched patients attending the dermatology IPD/OPD with positive skin swab results from July $1^{\text {st }}$ 2015 to June $31^{\text {st }} 2016$. The two groups were then compared in terms of bacterial culture results. Results: The mean gestational age of the study subjects at birth was 35.56 weeks (range: 30-39 weeks). The study sample consisted of 6 males and 3 females in LI group and 12 males and 6 females in the control group. Methicillin resistant Staphylococcusaureus (MRSA) was exclusively seen in LI patients, and Gram negative rods, Fusobacterium and Candida were found more in the LI patients than in the control group. The Bacteroidetes to Firmicutes ratio, lipophilic diphtheroids, Propionibacterium acnes, Fusobacterium and Micrococci were present more in the control group than in the LI patients. Conclusion: By knowing this microbiota, undue reliance on antibiotics can be reduced as these microorganisms may form normal commensals for the given micro environment. Furthermore, these organisms may be responsible for perpetuating the disease process by compounding the genetic keratinocyte barrier. What is known: Frequent skin infections are not uncommon in patients of lamellar ichthyosis. What is new: Methicillin resistant Staphylococcus aureus (MRSA) are commonly present in LI patients, and Gram negative rods, Fusobacterium and Candida are commoner in the LI patients than in the control group of patients.
\end{abstract}

Key words: Microbiota; Skin; Ichthyosis, Lamellar; Keratins; Keratinocytes; Skin Diseases, Infectious; Infant

\section{Introduction}

The skin does not only serve as an effective barrier between the organism and the environment, but it is in fact an ecosystem which is composed of different habitats rich in invaginations, pockets, and niches. Microorganisms inhabiting superficial skin layers are known as "skin microbiota" which includes bacteria, viruses, archaea and fungi (1). Lamellar ichthyosis (LI) is a severe, autosomal-recessive subtype of congenital ichthyosis which occurs because of genetic mutations in the keratinocyte lipid transporter adenosine triphosphate-binding protein leading to hyperkeratinization of the epidermis (2). In the neonatal period, such patients have an increased risk of developing life threatening complications such as malnutrition, severe dehydration, impaired thermoregulation, respiratory distress, infections, and aspiration pneumonia. Secondary sepsis is the most feared complication and one of the commonest causes of death in these patients as the skin acts as a constant portal of micro-organism entry due to defect in both physical and chemical barrier (3). Another important barrier is served by the biological mantle of the skin which has been linked notoriously in the pathogenesis of atopic dermatitis (4); however, there are no such studies on the composition of these microbial niches in LI.

\section{Material and Methods}

A comparative retrospective study was performed in patients with lamellar ichthyosis and age/sex controlled matched patients attending the dermatology IPD/OPD with positive skin swab results from July $1^{\text {st }} 2015$ to June $31^{\text {st }}$ 2016. An endpoint of 6 weeks postpartum was 
chosen because at this age infants have limited person-to-person contact, and are not exposed to a wide variety of microbes from the environmental sources. LI was diagnosed by complete family history, clinical examination and in doubtful cases skin biopsy was performed. Infants from the control group had no presence of pre-existing or dormant dermatological skin conditions. The patients who either had atopic diathesis or those who were on any kind of antibiotics, any active skin and skin tissue infections, steroidal medication, or used medicated soaps within the past 30 days of the study as well as those who had other forms of immunosuppression like HIV were excluded from the study. The two groups were then compared in terms of bacterial culture results.

\section{Samples}

All skin swab samples were taken within the first day of admission from four sites (nostrils, axillary and inguinal folds, arms). Cotton swabs saturated with sterile physiological saline (approximately $0.5 \mathrm{ml} / \mathrm{swab}$ ) were used to collect the cutaneous flora of each body site. A swab was rubbed vigorously, with rotation, for roughly $5 \mathrm{~s}$ over an approximate $8-\mathrm{cm} 2$ area of each body site. Samples were taken in a sterile and uniform manner by trained personnel. The institutional board approved the study protocol and informed consent was obtained from guardians in compliance with the Helsinki Declaration.

Table 1: Comparison of the skin bacterial composition

\begin{tabular}{|c|c|c|c|c|c|c|c|c|}
\hline \multirow[t]{2}{*}{ Microorganisms } & \multicolumn{4}{|c|}{$\begin{array}{c}\text { Controls } \\
(\mathrm{NC}=18 \text {,total samples } \mathrm{nc}=72)\end{array}$} & \multicolumn{4}{|c|}{$\begin{array}{l}\text { Lamellar Ichthyosis patients } \\
(\mathrm{NLI}=9 \text {,total samples } \mathrm{nLI}=36)\end{array}$} \\
\hline & Nostrils & s Axillary folds & Inguinal folds & Arm & Nostrils & Axillary folds & Inguinal folds & Arm \\
\hline \multicolumn{9}{|c|}{ AEROBES } \\
\hline Staphylococcus aureus & 7 & 1 & 1 & 2 & 5 & 3 & 5 & 5 \\
\hline MRSA & 0 & 0 & 0 & 0 & 2 & 0 & 1 & 3 \\
\hline $\begin{array}{l}\text { Staphylococcus } \\
\text { epidermidis }\end{array}$ & 4 & 7 & 7 & 13 & 1 & 2 & 3 & 5 \\
\hline Streptococcus sp. & 0 & 0 & 1 & 1 & 0 & 0 & 0 & 1 \\
\hline Group A Streptococcus & 0 & 0 & 0 & 1 & 1 & 2 & 3 & 3 \\
\hline Group D Enterococcus & 0 & 1 & 1 & 0 & 0 & 2 & 2 & 1 \\
\hline E. coli & 0 & 2 & 3 & 0 & 0 & 1 & 2 & 1 \\
\hline Enterobacter sp. & 0 & 7 & 4 & 1 & 0 & 3 & 1 & 2 \\
\hline P. aeruginosa & 1 & 0 & 0 & 0 & 2 & 1 & 1 & 3 \\
\hline Klebsiella & 3 & 3 & 3 & 1 & 1 & 1 & 2 & 1 \\
\hline Proteus sp. & 0 & 5 & 1 & 9 & 0 & 2 & 2 & 4 \\
\hline Lipophilic diphtheroids & 0 & 9 & 7 & 4 & 0 & 1 & 2 & 1 \\
\hline Micrococcus & 2 & 3 & 12 & 9 & 1 & 0 & 3 & 4 \\
\hline \multicolumn{9}{|c|}{ ANAEROBES } \\
\hline Propionibacterium acnes & 2 & 3 & 1 & 5 & 1 & 0 & 0 & 1 \\
\hline Clostridium spp. & 1 & 0 & 4 & 1 & 1 & 2 & 3 & 1 \\
\hline Bacteroides spp. & 2 & 7 & 7 & 11 & 1 & 3 & 4 & 6 \\
\hline $\begin{array}{l}\text { Pigmented Prevotella } \\
\& \text { Porphyromonas spp. }\end{array}$ & 0 & 3 & 1 & 2 & 0 & 1 & 1 & 0 \\
\hline Fusobacterium spp & 0 & 0 & 3 & 0 & 0 & 2 & 1 & 3 \\
\hline Candida spp. & 0 & 2 & 1 & 1 & 0 & 3 & 3 & 2 \\
\hline
\end{tabular}




\begin{tabular}{lccc} 
Variable & $\mathrm{X}^{2}$ & $\mathrm{p}$-value* & 95\% Confidence Interval(C.I.) \\
Lipophilic diphteroids & 3.82 & 0.05 & -0.1544 to 29.7822 \\
Propionibacterium acnes & 2.10 & 0.15 & -4.5154 to 20.5082 \\
Fusobacterium & 4.86 & 0.03 & 1.0146 to 27.9694 \\
Micrococci & 2.12 & 0.14 & -4.9306 to 29.4929 \\
Gram negative rods & 1.25 & 0.26 & -8.3687 to 29.2602 \\
Candida spp. & 6.68 & 0.0097 & 3.5290 to 32.8776 \\
\hline
\end{tabular}

\section{Bacteriologic methods}

Qualitative bacterial culture and sensitivities from the swabs obtained from all the subjects were performed. The swabs were also cultured on different media, consisting of Blood agar, MacConkey agar and EMB agar and incubated at $37^{\circ} \mathrm{C}$. MacConkey and Chocolate Agar media were used for aerobic and microaerophilic cultivation, respectively. Resultant growths were identified by a set of cultural and biochemical characteristics including Gram's stain, oxidase, coagulase and catalase tests. Appropriate dilutions were plated within $10 \mathrm{~min}$. Trypticase-soy-agar with Tween 8, eosinmethylenebluemedia (EBM), crystal violet agar, pseudomonas agar and Sabouraud glucose agar containing antibiotics (penicillin $20 \mathrm{U} / \mathrm{ml}$ and streptomycin, 40mg/ml) were used. Sabouraud agar plates were used to estimate the total counts of Candida albicans, whereas Trypticase-soy-agar with Tween 80 was used for lipophilic diphtheroids. Sabouraud agar plates were incubated at room temperature. Sheep blood agar plates were used to estimate the total count of bacteria. The total counts for C. albicans were estimated on Sabouraud agar plates and added to the total bacterial counts. Organisms were classified according to their response to biochemical tests and by their growth and/or morphology on selective or differential media. Colonial pigment, catalase production, coagulase production, oxidative or fermentative metabolism of glucose, production of spores and motility were used to identify the organisms.

\section{Detection of methicillin resistance}

Methicillin sensitivity tests were performed by the Kirby-Bauer disk diffusion on media growing Staphylococcus aureus. The Clinical and Laboratory Standards Institute (CLSI) guidelines (2006) recommended cefoxitin disc diffusion method for the detection of MRSA. This was performed by using a $30 \mu \mathrm{g}$ cefoxitin disc and an inhibition zone diameter
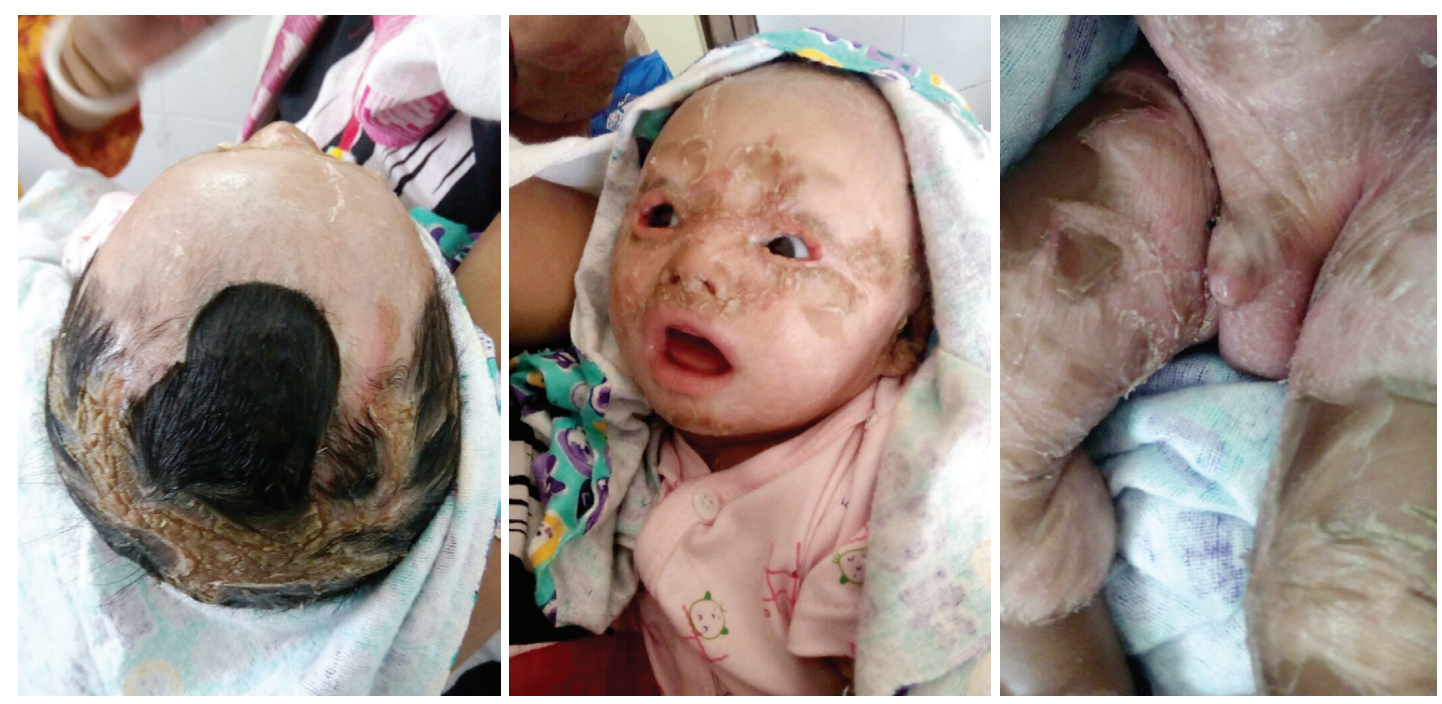

Figure 1. Clinical features of a patient of LI 
of $\leq 19 \mathrm{~mm}$ was reported as Methicillin resistant and $\geq 20 \mathrm{~mm}$ was considered as Methicillin sensitive.

\section{Statistical Analysis.}

Student t-test was used to test for differences between proportions. All tests were then 2-tailed and $p \leq 0.05$ was considered statistically significant.

\section{Results}

The mean gestational age at birth was 35.56 weeks (range: 30-39 weeks). There were 6 males and 3 females in LI group and
12 males and 6 females in the control group. In the control group the ratio of age, sex matched ratio was 2:1. Age ranged from 4 weeks to 9 years. History of collodion membrane was present in $77.78 \%$ and consanguineous marriage in $55.56 \%$. Staphylococcus $(80.56 \%)$ was the predominant organism in the controls followed by bacteroides (37.50\%). A similar trend was seen in $38.89 \%$ of LI group patients with staphylococci.

Bacteroidetes to Firmicutesratios (B/F ratios). The Bacteroidetes-to-Firmicutes ratio (B/F ratio) was 0.62 in the controls and 0.31 in lamellar ichthyosis patients. Although both

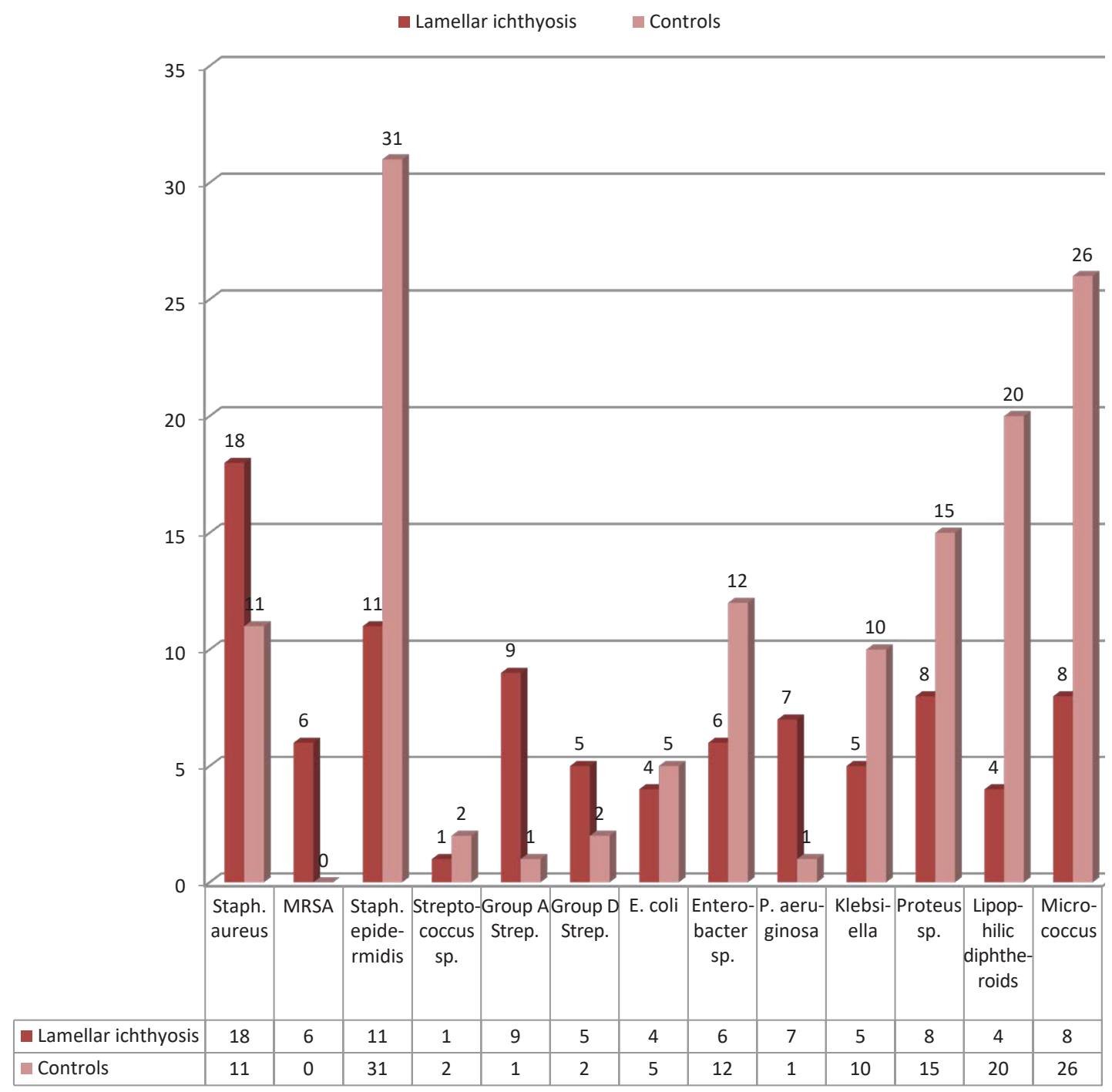

Chart 1. Aerobic microbiota in $\mathrm{LI}$ and control 


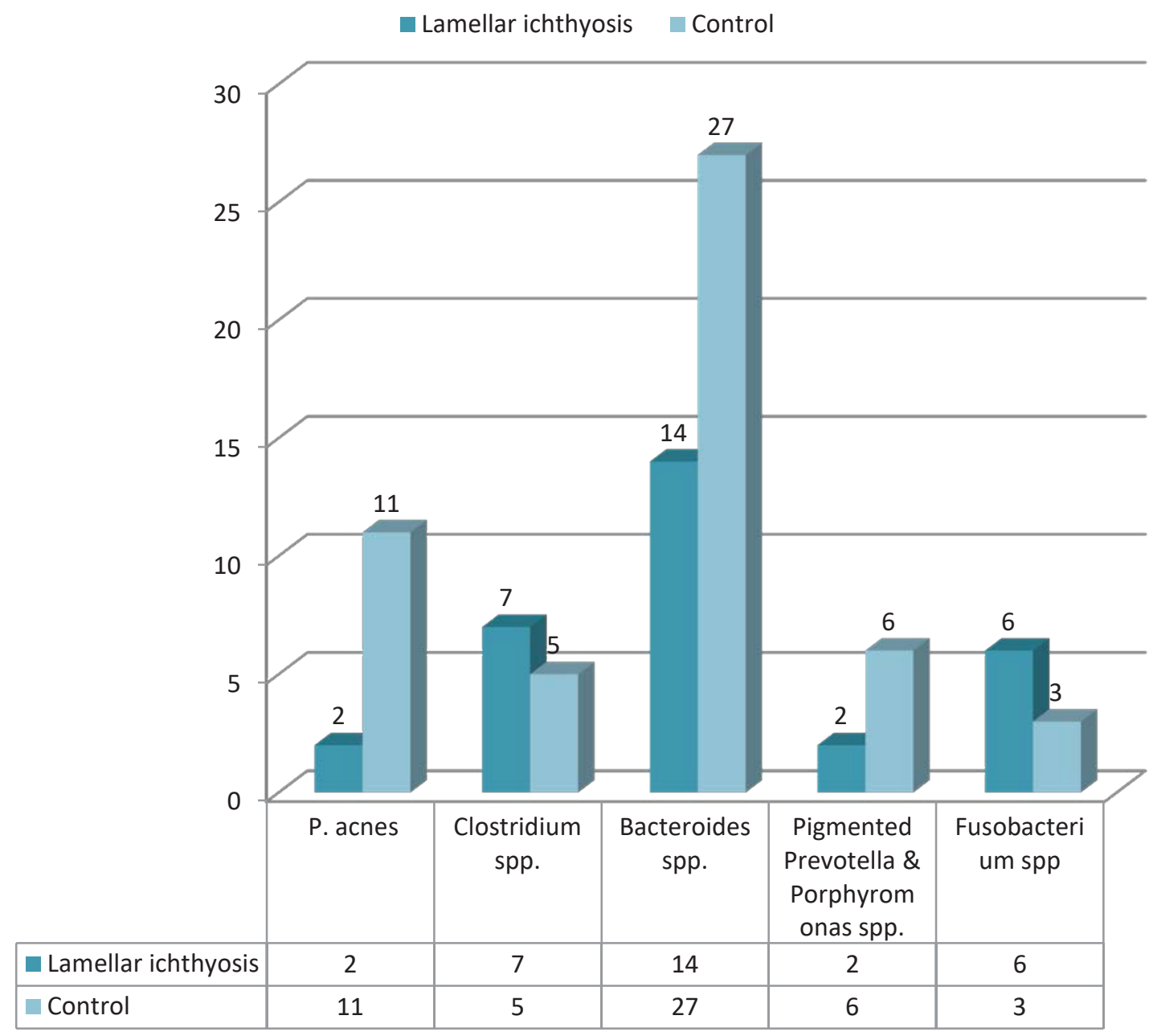

Chart 2. Anaerobic microbiota in LI and control

cohorts showed an increased firmicutes (ZScore $=3.0391$. The $p$-value $=0.00236)$, LI cohort showed greater preponderance of firmicutes, especially of staphylococcus aureus and group A streptococcus (S. pyogenes).

Methicillin resistant Staphylococcus aureus (MRSA). MRSA colonization was seen exclusively in LI cohort, constituting $33.33 \%$ of $S$. aureus flora.

Lipophilic diphtheroids and Propionibacterium acnes. Lipophilic diphtheroids constitute $11.11 \%$ in LI group in contrast to $27.78 \%$ in the control subjects. Although P. acnes is not as populous in paediatric population as in adults, its presence was found to be even lower in LI group (5.6\%) in comparison to the controls (15.28\%).

Fusobacterium was found in more LI patient microbiome (16.67\%) than in the controls
$(4.17 \%)$ and its increased presence may point out to a precursor environment for skin infections.

Micrococci. Micrococci form a major part of paediatric microbiome. In our study there was decreased sample positivity in case of LI patients $(22.22 \%)$ as compared to the controls (36.11\%).

Gram negative rods comparison. Aerobic Gram negative bacilli comprising of Enterobacter, Proteus, Klebsiella were found more in $\mathrm{LI}$ cohort (52.78\%) than in the control group (51.39\%).

Fungal population. The predominant fungal species isolated from both the groups was Candida but it was present more in the samples from LI group (22.22\%) than in the control samples (5.56\%). 


\section{Differential Microbial Composition accor- ding to Niche}

Nostrils. Aerobes predominate in both the control and LI group. Staphylococci formed the most populous microbial population in the nares in both group-S.aureus and S.epidermis in the controls but in the LI patients MRSA was isolated from nares. Similarly GAS inhabitation (like MRSA) pointed towards more pathogenic microbial constituents in LI.

Axillary folds. Lipohilic diphtheroids formed the majority of isolates in the control group from this site $(p=0.05, x 2=3.75)$. In the staphylococcal group, $S$. epidermis formed the majority in the control group, whereas in the LI group, S.aureus was found in a greater number of samples in comparison to S. epidermis. GAS and Group D enterococci were found as unusual inhabitants in case of LI patients (none isolated in case of controls). In anaserobes, P.acnes was conspicuously absent in the axillae samples of LI

Inguinal folds. Samples from inguinal creases showed the increased presence of $S$. aureus (with the presence of MRSA in 1 culture), which replaced the normally present commensal-S.epidermis as seen in the control group. (S.aureus and MRSA population control vs. LI was found to be markedly higher in LI with $p=0.0008, \chi 2=11.23)$. Pathogenic GAS and group $D$ Enterococci were found exclusively in LI samples. As in axillae samples, lipohilic diphtheroids and P.acnes $(P$. acnes generally also seen in lesser quanta in paediatric population) are decreased in concentration which may be due to the xerotic environment in LI patients and increased sebum film fragility. Candida spp. and Clostridia are seen as increased commensal population in $\mathrm{LI}$ as compared to the controls (statistically not significant for the site, $p=0.54$ ).

Volar aspect of forearms. The similar trend of increased presence of S.aureus instead of S. epidermis in isolates obtained from other sites in LI patients persisted at this site as well. Interestingly, this niche provided the most suitable environment for the presence of MRSA in LI group (S. aureus and MRSA population control vs. LI was found to be markedly higher in LI with $p=0.0001, \chi 2=14.99$ ). Pseudomonas was isolated in $33.33 \%$ of cultures from the forearm samples in LI patients as compared to none in the controls. Bacteriodes in particular were found in a greater number of LI samples (66.67\%) as compared to the controls (38.89\%), but statistically this was not found to be significant $(p=0.18)$. Similarly, fusobacterium and candida form a greater part of the commensals in LI skin as compared to that in the normal paediatric skin.

\section{Discussion}

The difference in the constituents of the microbial flora may be attributed to the defect in the keratinocyte barrier, usage of antibiotics, retinoids and corticosteroids. Infants' skin microbiota is derived from the mode of delivery, body of the mother and other human contacts and from various inanimate objects. Four major groups of microbial communities residing at different body sites form the microbiome of a neonate: Firmicutes, Actinobacteria, Bacteroidetes, and Proteobacteria $(4,5)$. Specific groups of microorganisms colonize distinct anatomical niches. The most numerous microbes are well-defined resident floras which are constantly present on the body surfaces and may prevent colonization by pathogens and a possible disease. Commensal microorganisms are in mutualistic symbiosis and they contribute to human health through the production of defence molecules. Transient skin flora temporarily colonizes the skin and is unable to remain in the body for a long period of time due to the competition from the resident microbes. They are not pathogenic under normal conditions (6-8).

No study has been undertaken so far to decipher the composition of the skin flora in LI. In this study, methicillin resistant Staphylococcous aureaus (MRSA) was exclusively seen in LI patients, and Gram negative rods, Fusobacterium and Candida were observed more in the LI patients. The Bacteroidetes-toFirmicutes ratio, lipophilic diphtheroids, Propionibacterium acnes, Fusobacterium and Micrococci were present more in the control group than in the LI patients. Due to disrupted corneocyte TGM1 there is a failure of proper and uniform lipid layer in LI patients, which reflects in the change of microbiome of the skin from lipophilic organisms to organisms which thrive in dry skin. 
The importance of reversal of Bacteroides to firmicutes ratio ratio stems from both pathogenic as well as therapeutic views. Pathogenetically, the phylum Firmicutes consist of the following genera-Bacillus, Listeria, Staphylococcus, Streptococcus, Enterococcus, and Clostridium-which are responsible for major SSTIs. In normal paediatric skin microenvironment, Firmicutes for example, $S$. epidermis, form the majority in a healthy neonate's skin but as seen in our study as well as in other studies involving patients of atopic dermatitis and psoriatic plaques etc there is an increase in the relative concentration of S.aureus population (4). Therapeutically, delving in this microbial composition, tipping the balance towards bacteroides by topical or ingested flora correction and use of barrier emollients and by altering the skin $\mathrm{pH}$ may reduce the severity of the disease.

Staphylococcus epidermidis is a Grampositive bacterium and it comprises more than $90 \%$ of the aerobic resident flora. S. epidermidis provides an added level of protection against certain common pathogens via production of lantibiotics, which are lanthionine containing antibacterial peptides and via activation of TLR-2. S. epidermidis also inhibits biofilm formation and nasal colonization by $S$. aureus. In this study, the most common aerobic bacteria on the skin of LI were Staphylococcous aureus followed by Staphylococcus epidermidis. This indicates the higher susceptibility of patients of LI to infections owing to the loss of antibacterial properties of Staphylococcous epidermidis and overgrowth of pathogenic Staphylococcous i.e. Staphylococcous aureus. Stratum corneum of infant is better hydrated than of adults hence microbiome of the infant skin resembles closer that of the relatively moister skin sites in the adults $(5,6)$.

Under anaerobes, Bacteroides were abundant in both groups, whereas the second most common organism was Clostridium spp. in $\mathrm{LI}$ and P.acnes in the control group. In contrast to the adults, Firmicutes predominate on the infant skin but the $\mathrm{B} / \mathrm{F}$ ratio is decreased to a statistically low value in case of LI patients, further understating the presence of organisms most frequently implicated in SSTIs (especially pathogenic Staphylococci, GAS etc.).

MRSA carriage in LI patients further undermines the perturbed biological, physical as well as chemical barrier of the skin. The new- born having lamellar ichthyosis is born encased in a collodion membrane that sheds within 10-14 days after which the newborn is exposed to a plethora of antigens, this delay in antigen presentation particularly that of microbial origin compounded by keratinocyte barrier dysfunction may lead to differential commensal microbial niches in comparison to their normal counterparts as observed in this study.

Finally, increased interventional procedures in LI patients such as frequent cannulation, catheters and blood draws become more perilous due to the change in the commensal population, especially, invasive candidiasis and septicemia.

There are certain limitations to this study. We diagnosed LI by clinical and histological findings, whereas DNA-based molecular genetic testing for TGM1, ABCA12, ALOXE3 and ALOX12B could not be performed. Also, 16S rRNA molecular analysis could not be performed to identify bacteria due to the lack of resources. Studies involving larger number of patients of different ethnic group will be more desirable.

\section{Conclusion}

This study revealed the altered microbiome tipping towards the presence of pathogenic flora even in the absence of any clinical infection in LI patients. This milieu may act as a precursor to the recurrent infections seen in LI patients. In-depth knowledge of the altered flora of these patients may explain perpetuation and flare up of the disease process itself. By knowing the microbiome of patients with LI, preventive measures can be taken to decrease the load of pathogenic bacteria and reconstitute a positive symbiotic biological mantle thereby decreasing the chances of skin infections, sepsis and thus heavy reliance on antibiotics.

\section{Author's contributions:}

MS designed and supervised the project, supervised data collection and analysis, and first drafted the manuscript. MP assisted in data management, was responsible for sample management, and revised the manuscript for important intellectual content. All authors approved the final manuscript as submitted 
and agree to be accountable for all aspects of the work.

\section{Abbreviations \\ LI - Lamellar ichthyosis \\ MRSA - Methicillin resistant Staphylococcus aureus}

\section{References}

1. Madison KC. Barrier function of the skin: „la raison d'etre" of the epidermis. J Invest Dermatol. 2003;121 (2):231-41.

2. Singh M, Kaur M, Kaur R, Singh S. Severe ectropion in lamellar ichthyosis managed medically with oral acitretin. Pediatr Dermatol. 2018;35(2):e117-20.

3. Murgu AM, Crişcov IG, Fotea S, Baciu G, Chiriac A, Tarca E, et al. Particularities of the management and the treatment in a rare sepsis with Candida tropicalis of a Collodion baby: case report. Medicine (Baltimore). 2017;96(51):e9387.

4. Baviera G, Leoni MC, Capra L, Cipriani F, Longo G, Maiello N, et al. Microbiota in healthy skin and in atopic eczema. Biomed Res Int. 2014;2014:436921.

5. Grice EA, Kong HH, Renaud G, Young AC, Bouffard GG, Blakesley RW, et al. A diversity profile of the human skin microbiota. Genome Res. 2008;18(7):1043-50.

6. Capone KA, Dowd SE, Stamatas GN, Nikolovski J. Diversity of the human skin microbiome early in life. J Invest Dermatol. 2011;131(10):2026-32.

7. Ward TL, Dominguez-Bello MG, Heisel T, Al-Ghalith G, Knights D, Gale CA. Development of the human mycobiome over the first month of life and across body sites. mSystems. 2018;3(3).

8. Chu DM, Ma J, Prince AL, Antony KM, Seferovic MD, Aagaard KM. Maturation of the infant microbiome community structure and function across multiple body sites and in relation to mode of delivery. Nat Med. 2017;23(3):314-26.

\section{Studija o mikrobiomu kože kod pacijenata sa lamelarnom ih- tiozom}

\section{Sažetak}

Uvod. Lamelarna ihtioza je genetski poremećaj keratinizacije i česte kožne infekcije kod ovih pacijenata mogu biti rezultat promene u normalnoj flori kože koja deluje $u$ adendumu da bi probila fizičku barijeru. Materijali i metode. Izvedena je komparativna retrospektivna studija kod pacijenata sa lamelarnom ihtiozom i kod kontrolnih pacijenata istog pola i starosti koji su došli na odeljenje dermatologije poliklinike i bolničkog dela sa pozitivnim rezultatima brisa kože u periodu od 1 . jula 2015. do 31. juna 2016. godine. Rezultati bakterioloških kultura poređeni su između dve grupe. Rezultati. Prosečna gestaciona starost ispitanika na rođenju bila je 35,56 nedelja (raspon između 30 i 39 nedelja). Studija je obuhvatila šest muških i tri ženska pacijenta u grupi sa lamelarnom ihtiozom i šest pacijentkinja u kontrolnoj grupi. Methicillin resistant Staphylococcus aureus
(MRSA) viđen je samo kod pacijenata sa lamelarnom ihtiozom, a Gram-negativni štapići, Fusobacterium i kandida pronađeni su više kod pacijenata sa lamelarnom ihtiozom nego u kontrolnoj grupi. Odnos bakteroida i firmikuta lipofilni difteroidi, Propionibacterium acnes, Fusobacterium i Micrococci bili su više prisutni u kontrolnoj grupi nego kod pacijenata sa lamelarnom intiozom. Zaključak. Saznanje o mikrobiomu kod lamelarne ihtioze može doprineti racionalnoj upotrebi antibiotika, jer mnogi od ovih mikroorganizama mogu predstavljati komensale u datoj sredini, ali mogu i doprinositi održavanju patološkog procesa u koži. Staphylococcus aureus rezitentan na meticilin (MRSA) je često prisutan, a Gram-negativni štapići, Fusobacterium i kandida češći su kod pacijanta sa lamelarnom ihtiozom nego kontrolnih ispitanika.

Ključne reči: Mikrobiota; Koža; Lamelarna intioza; Keratin; Keratinociti; Infektivne kožne bolesti; Novorođenče

Received 17.12.2019.

Accepted 22.01.2020. 